\title{
HIKAYAT NABI MIKRAJ: SEBUAH ANALISIS INTERTEKSTUAL
}

\author{
HIKAYAT NABI MIKRAJ: AN INTERTEXTUAL ANALYSIS
}

\author{
Abdul Lathif, Asep Yudha Wirajaya \\ Universitas Sebelas Maret \\ Latiefibnkiswanto@gmail.com; asepyudha.w@gmail.com
}

\begin{abstract}
ABSTRAK
Tujuan penelitian ini adalah untuk mengetahui hubungan intertekstual naskah Hikayat Nabi Mikraj dengan Hadis Sahih Bukhori tentang isra mikraj. Kisah spriritual isra mikraj merupakan kisah yang sangat sakral bagi umat Islam. Bahkan, di masa sekarang banyak tulisan yang masih membahas peristiwa suci tersebut dari berbagai macam perspektif. Begitu pula orang-orang dahulu telah mengabadikan kisah tersebut dalam berbagai macam tulisan, termasuk dalam bentuk prosa hikayat. Tentunya, tulisan tersebut bersumber dari cerita isra mikraj yang terdapat dalam teks-teks hadis yang mutawatir, seperti Sahih Bukhari, Sahih Muslim, Sunan at Tirmidzi, dan lain sebagainya. Salah satu naskah kuno yang berhasil dipreservasi adalah Hikayat Nabi Mikraj. Naskah ini berisi teks tentang peristiwa isra mikraj Nabi Muhammad SAW. Dengan demikian, dapat diasumsikan bahwa keberadaan teks Hikayat Nabi Mikraj tidak dapat dilepaskan dari teks-teks sebelumnya, yaitu teks yang terdapat dalam hadis mutawatir.
\end{abstract}

Kata kunci: interteks, hadis, isra mikraj, dan hikayat.

\begin{abstract}
The purpose of this study was to determine the intertextuality relationship of the text of the Story of the Prophet Mikraj with the Sahih Bukhori Hadith about isra mikraj. The spiritual story of isra mikraj is a very sacred story for Muslims. Even today many writings still discuss the sacred event from various perspectives. Similarly, the ancients have perpetuated the story in a variety of writings, including in the form of story prose. Of course, the writing is sourced from the story of isra mikraj contained in muthatith hadith texts, such as Sahih Bukhari, Sahih Muslim, Sunan at Tirmidzi, and so forth. One ancient text that was successfully preserved was the Hikayat Nabi Mikraj. This manuscript contains a text about the events of the Prophet Muhammad SAW. Thus, it can be assumed that the existence of the text of the Hikayat Nabi Mikraj cannot be separated from the previous texts, namely the text contained in the muthatith Hadith.
\end{abstract}

Keywords: intertextuality, hadith, isra mikraj, and saga

\section{PENDAHULUAN}

Keberadaan sebuah naskah lama merupakan aset berharga bagi kerohanian serta kekayaan khazanah kebudayaan bangsa Indonesia. Robson dalam Muzakka 
Tuah Talino

Tahun XIV Volume 14 Nomor 1 Edisi 31 Juli 2020

ISSN 0216-079X E-ISSN 2685-3043

Balai Bahasa Kalimantan Barat

(2018: 341) menyatakan bahwa sastra lama yang tertulis dalam naskah lama merupakan warisan ide, cita-cita, dan pernyataan sikap nenek moyang yang turuntemurun yang memiliki peran besar dalam pembangunan mental dan karakter bangsa Indonesia dalam pembangunan bangsa yang seutuhnya.

Keberadaan naskah lama terutama dalam hal ini adalah naskah Melayu yang beragam tidak akan bisa diambil, baik pelajaran maupun kajian, misal tidak ada sentuhan filologis. Filologi menurut Baried, dkk. (1994:2) merupakan ilmu yang berhubungan dengan karya sastra masa lampau yang terkandung dalam naskah tulisan tangan. Naskah lampau yang dimaksudkan adalah berbanding lurus dengan pengertian manuskrip Melayu. Mamat (1988:7) mendefinisikan bahwa yang dimaksud manuskrip atau naskah Melayu adalah sesuatu yang bertuliskan Jawi atau Rumi dengan bahasa Melayu yang ditulis dengan tangan di atas bahanbahan, seperti kertas, kulit, daun lontar, bilah bambu, gading, kayu, kain dengan isi kandungan dan jangka waktu yang tidak terbatas.

Naskah-naskah Melayu pada saat ini telah tersebar di seluruh penjuru dunia. Mengenai jumlah, sebenarnya tidak ada penghitungan pasti sampai dengan saat ini. Para ahli memperkirakan angka-angka di antara 5.000 s.d. 10.000 buah (Rujiati Mulyadi, 1991:11). Namun, kebenaran ataupun jumlah mana yang mendekati kenyataannya tidak ada yang mengetahui.

Selain pendataan jumlah naskah, naskah kuno yang berumur lebih dari 50 tahun tentu memerlukan perawatan dan penanganan khusus. Keringkihan bahan pustaka yang pada konteks ini adalah naskah Melayu membuat munculnya upayaupaya penanganan. Salah satunya adalah digitalisasi naskah. Hingga saat ini, sudah banyak lembaga-lembaga, yayasan-yayasan, universitas-universitas yang melakukan digitalisasi naskah. Di Indonesia, misalnya terdapat di Perpustakaan Nasional Republik Indonesia, Puslitbang Lektur, dll. Di luar negeri, misalnya terdapat di Universitas Leiden, Universitas Leipzig, dsb.

Selain di universitas, perpustakaan nasional berbagai negara juga mengadakan upaya digitalisasi. Misalnya di Bibliothèque nationale de France (Perpustakaan Nasional Prancis). Di sana, penulis menemukan naskah-naskah Melayu yang telah terdigitalisasi dengan penandaan menggunaan istilah Malayo Polynesian. Salah satu naskah Melayu yang penulis temukan adalah naskah Hikayat Nabi Mikraj. Naskah ini tercatat dengan kode nomor inventaraisasi naskah, yaitu Malayo Polynesian-58. Naskah ini bertarikh $1825 \mathrm{M}$ atau bertepatan dengan $1240 \mathrm{H}$. Naskah ini ditulis oleh Muhammad Cing Sa'idullah dalam aksara Arab/Jawi dengan menggunakan bahasa Melayu. Sesuai namanya, naskah ini adalah bentuk hikayat dari peristiwa isra mikrajnya Nabi Muhammad di waktu malam. Perjalanan suci dari Makkah menuju Baitul Maqdis kemudian dilanjutkan perjalanan sakral menuju Sidratil Muntaha.

Cerita peristiwa tentang isra Mikraj amat populer di kalangan kaum muslimin. Peristiwa yang jauh dari nalar dilakukan oleh junjungan besar umat Islam, Nabi Muhammad yang dilakukan dalam satu malam. Di awal penceritaannya, banyak orang Islam di zaman Nabi murtad karena berfikir atas kemustahilannya. Namun, peristiwa ini sangat diyakini kebenarannya oleh umat Islam, bahkan dianggap sebagai salah satu bentuk kemukjizatan Rasulullah saw. Di masa sekarang, banyak kalangan masyarakat Islam Nusantara yang melakukan 
Tuah Talino

Tahun XIV Volume 14 Nomor 1 Edisi 31 Juli 2020

ISSN 0216-079X E-ISSN 2685-3043

Balai Bahasa Kalimantan Barat

berbagai kegiatan untuk memeringatinya. Mereka berharap dapat mengambil hikmah dari peristiwa isra mikraj tersebut. Salah satu contoh adalah tradisi masyarakat Gorontalo dalam memperingati peristiwa ini, seperti pada tulisan Tohopi (2012). Selain untuk memperingati kesakralannya, di Indonesia peristiwa tersebut dijadikan sebagai hari libur nasional.

Kepopuleran penceritaan isra mikraj yang diyakini sebagai realita telah mengilhami terciptanya banyak cerita-cerita ataupun karya-karya setelahnya. Naskah Hikayat Nabi Mikraj hanya satu dari sekian banyak korpus-korpus yang mengangkat tema isra mikraj. Kisah isra mikraj telah termaktub dalam hadis mutawatir, seperti Sahih Bukhari, Sahih Muslim, Sunan At Tirmidzi dll. Hadishadis mutawatir tersebut saling melengkapi satu sama lain. Selain di dalam Al hadis, kisah ini juga tertulis dalam Surat Kabar Neraka, Hikayat Abdullah Asyir dan Dayang Rohani, Hikayat Raja Jumjumah, Syair Neraka, Syair Azab dalam Neraka, Syair Kanak-Kanak, dan Syair Alif-Ba-Ta. (Suryadi, 2015)

Berdasarkan uraian di atas, menarik untuk dikaji bahasan tentang keterkaitan antara salah satu teks hasil tulisan pengarang dengan salah satu hadis yang menerangkan peristiwa isra mikraj . Dengan demikian, sumber data Hikayat Nabi Mikraj yang tersimpan di Bibliothèque nationale de France dan hadis Bukhari nomor 3887 yang membahas tentang peristiwa isra mikraj dapat digali hubungan interteks antara keduannya. Dalam tulisan ini akan dibahas mengenai hubungan intertekstual yang terjadi antara teks dalam bentuk hikayat dan matan hadis Sahih Bukhari. Hadis Bukhari nomor 3887 berkedudukan sebagai teks hipogram dalam penelitian ini, sedangkan Hikayat Nabi Mikraj dalam hal ini digunakan oleh penulis sebagai teks turunannya. Selain itu, akan ada kajian menarik terkait kisah isra mikraj yang diyakini sebagai peristiwa yang benarbenar terjadi (fakta) digubah menjadi teks turunan yang berupa hikayat (fiksi).

\section{METODE}

Penelitian ini merupakan penelitian dengan metode studi pustaka. Mardalis (2004) menjelaskan bahwa yang dimaksud studi pustaka adalah mengumpulkan informasi serta data dengan menggunakan berbagai material yang ada di perpustakaan. Material tersebut berupa dokumen, buku-buku, catatan, kisah sejarah, dsb. Kemudian, yang menjadi objek material penelitian ini adalah hadis Sahih Bukhari nomor 3597 yang merupakan hadis mutawatir yang menjelaskan sabda Nabi Muhammad SAW saat menceritakan kisah perjalanan isra ke Baitul Maqdis dan perjalanan mikraj ke Sidratul Muntaha dan teks Hikayat Nabi Mikraj yang berbentuk prosa berbahasa Melayu. Adapun objek formalnya adalah hubungan intertekstualitas kedua teks yang sama-sama menceritakan perihal peristiwa isra mikraj.

Dalam penelitian ini, penulis melakukan sebuah kajian dengan pendekatan intertekstual antara kedua teks. Metode pengumpulan data penelitian dilakukan dengan metode studi pustaka, yaitu dengan teknik membaca dan mencatat datadata kemudian penulis klarifikasi data-data tersebut sesuai hasil bacaan pada kedua teks. Data-data yang sudah terkumpul tersebut kemudian dianalisis dengan menggunakan pendekatan intertekstual. Pendekatan intertekstual dipilih karena Hikayat Nabi Mikraj (HNM) memiliki hubungan erat dengan peristiwa isra 
mikraj. Teeuw (1982) mengatakan bahwa banyak dari karya sastra yang lahir di era modern merupakan tranformasi dari teks-teks lama dalam bentuk saduran, salinan, dan sebagainya. Dengan demikian, penulis menggunakan pendekatan intertekstual guna melihat hubungan kedua teks, yakni hubungan teks transformasi (Hikayat Nabi Mikraj) dengan hipogramnya (Sahih Bukhari no 3597). Hasil kajian ini akan penulis sajikan dalam bentuk deskriptif. Harapannya agar pembaca dapat dengan mudah memahami tulisan ini.

\section{PEMBAHASAN}

\section{Hikayat Nabi Mikraj}

Hikayat Nabi Mikraj adalah sebuah naskah prosa berbahasa Melayu yang ditulis oleh Muhammad Cing Sa'idullah. Sayangnya, sampai dengan artikel ini dibuat, belum ditemukan data lengkap terkait identitas penulis naskah. Namun jika dilihat dari namanya, penulis berhipotesis bahwa Muhammad Cing Sa'idullah adalah penulis yang berasal dari Betawi. "Cing" merupakan penyederhanaan istilah dari "Encing" yang memiliki arti "Paman" atau "Bibi", yang merupakan adik, baik dari ayah maupun ibu.

HNM adalah teks yang ditulis dengan huruf Arab Melayu atau Jawi. HNM ditulis pada tahun $1825 \mathrm{M}$ atau kalau dikonversikan ke dalam tahun Hijriah adalah tahun $1240 \mathrm{H}$. Informasi yang terkait dengan angka tahun selesainya penulisan naskah dan identitas penulis naskah didapatkan dari halaman kolofon $H N M$ yang dapat ditemukan pada halaman belakang naskah. Di halaman tersebut tertulis bahwa jika naskah $H N M$ ini adalah tulisan Muhammad Cing Sa'idullah (Sa'idullah, 1825). Selain itu, penulis juga menemukan tahun penulisan jika naskah ini ditulis pada 20 hari (menunjukkan tanggal 20) bulan Februari hari Arba' (menunjukkan hari Rabu) waktu jam pukul dua belas tengah hari (menunjukkan pukul 12.00) tahun 1825 M (Sa'idullah, 1825).

Gambar 1

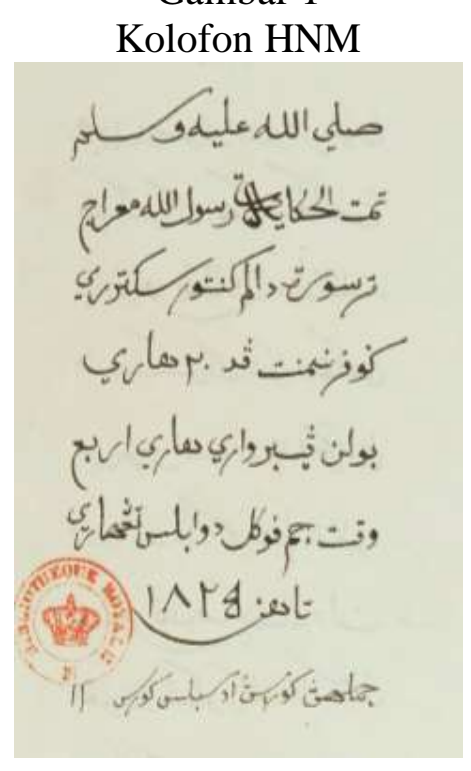


Tuah Talino

Tahun XIV Volume 14 Nomor 1 Edisi 31 Juli 2020

ISSN 0216-079X E-ISSN 2685-3043

Balai Bahasa Kalimantan Barat

Naskah HNM terdapat dalam koleksi Bibliothèque nationale de France (Perpustakaan Nasional Prancis). Naskah Melayu ini telah terdigitalisasi dengan penandaan menggunaan istilah Malayo Polynesian. Lebih jelasnya, naskah ini tercatat dengan kode nomor inventarisasi, yaitu Malayo Polynesian-58.

$H N M$ ini adalah naskah yang mengisahkan cerita spiritual Nabi Muhammad SAW saat melakoni perjalanan isra' mikraj. Perjalanan sakral yang dilakoni Nabi Muhammad dari Mekkah menuju Baitul Maqdis dan dilanjutkan perjalanan ke langit sampai Sidrotil Muntaha. Isra mikraj bukanlah sekedar perjalanan individu Nabi atau bukan pula darmawisata Nabi menyaksikan kekuasaan Allah swt yang tiada berbatas. Namun, di balik semua peristiwa tersebut, ternyata isra mikraj merupakan peristiwa yang sangat berarti bagi umat Islam. Beberapa pakar menegaskan bahwa perjalanan Isra' Mi'raj bukanlah suatu peristiwa individu biasa yang menampilkan perjalanan yang dilakukan Nabi Muhammad SAW dengan tujuan hanya untuk melihat-lihat alam semesta, tetapi perjalanan isra mikraj tersebut mempunyai arti mendalam bagi kehidupan Nabi, baik secara pribadi maupun bagi umat manusia seluruhnya.(Maria, 2015) Dengan begitu sakralnya peristiwa tersebut membuat cerita ini menjadi sangat populer di kalangan umat Islam. Hal itu pula yang melatarbelakangi banyak versi ditulis atau disalin tentang peristiwa perjalanan suci tersebut.

\section{Hadis Bukhari Sebagai Teks Hipogram HNM}

Beberapa teks Melayu yang telah ada sudah barang tentu tidak akan ada jika teks hadis sebagai bahan acuan tidak ada. Dalam konteks ini, penulis memposisikan hadis Sahih Bukhari dalam Kitab l-'Manaqibi l-'Anshar bab nomor 42, yaitu Babu l- 'Mi'rāj pada nomor hadis 3887 cetakan Dar l-'kutub l-'Ilmiyah (Al-Bukhari, 2017) sebagai salah satu teks hipogram. Agak sulit menentukan teks hipogram dengan menggunakan hadis sahih. Mengingat pula bahwa penulis yang berpodaman pada kutub l-sitta yang oleh sebagian besar ulama dianggap sebagai acuan keilmuan hadis. Dalam kutub l-`sitta tidak dijumpai hadis yang benar-benar lengkap mengisahkan kisah isra mikraj. Namun, dapat diketahui antara hadis satu dan hadis yang lainnya saling melengkapi dan saling memperkuat.

Karena sifatnya saling melengkapi, penulis membatasi kajian dengan objek hadis secara khusus pada hadis Bukhari 3887 tanpa maksud mengesampingkan hadis lainnya. Pertimbangan ini penulis ambil dengan pemikiran bahwa hadis Bukhari dapat dikatakan sebagai hadis sahih yang memiliki kedudukan terkuat dalam kekuatan sanad dan matannya. Banyak hadis lain yang tidak akan memiliki posisi kuat atau juga akan mendapat predikat hadis kuat berdasar pertimbangan serta perbandingan dengan Sahih Bukhari.

Selain menggunakan cetakan Dar l-`kutub l-'Ilmiyah untuk memudahkan pembahasan, penulis juga menggunakan tafsir hadis yang terdapat dalam buku Ringkasan Hadis Al-Bukhari tulisan Al Imam Zainuddin Ahmad yang telah diterjemahkan oleh Drs. Achmad Zainuddin yang tertulis pada halaman 743 749. Adapun teks hadis Sahih Bukhari ditulis pada kisaran tahun 850-an Masehi, yaitu pada masa hidupnya Muhammad bin Ismail Al-Bukhari (Nama asli Bukhari). Kemudian, peristiwa isra mikraj terjadi pada malam tanggal 27 Rajab pada tahun ke-10 kenabian atau kisaran antara tahun $620-621 \mathrm{M}$. 


\section{Perbandingan Nama dan Peristiwa dalam Kedua Teks}

Dalam sebuah teks, hampir selalu terdapat unsur nama di dalamnya. Nama yang penulis maksud adalah kata yang digunakan untuk menyebut atau memanggil sesuatu. Baik itu perihal tempat, barang, binatang, tumbuhan,dsb. (KBBI V Luring, 2016). Dalam HNM dan Sahih Bukhari nomor 3887 disebutkan beberapa nama. Dalam penyebutanya, nama yang terdapat dalam kedua teks ini memiliki beberapa kesamaan dan juga beberapa perbedaan. Selain nama, dalam $H N M$ dan Sahih Bukhari nomor 3887 juga dijumpai persamaan dan juga perbedaan dalam penyajian peristiwa. Adapun perbandingan nama dan peristiwa dalam kedua teks adalah sebagai berikut.

1. Dalam $H N M$, dijelaskan bahwa cerita isra mikraj merupakan cerita yang disampaikan Nabi Muhammad SAW. kepada Abbas R.A. dan sahabat Nabi yang lain. (Sa'idullah, 1825:1), sedangkan dalam Sahih Bukari 3887 tidak dijelaskan demikian. Karena perawi ${ }^{1}$ yang meriwayatkan Sahih Bukhari nomor 3887 adalah Malik bin Șa'șa'ah, seperti dalam penggalan perawi hadis berikut.

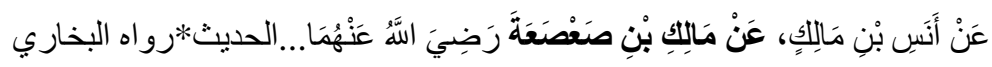

('An anasi bni malikin, 'an māliki bni șa 'ṣa'ah raḍiya 'l-Lāhi anhumā)

Dalam penggalan perawi hadis diatas sangat jelas bahwa perawi hadis adalah Malik bin Sha'sha'ah. Dalam HNM juga memliki kejanggalan cerita, yaitu penempatan nama Abbas R.A. sebagai sahabat yang mendengar kisah dari Nabi SAW. mengenai isra mikraj. Hal ini disebabkan Abbas R.A. adalah paman Nabi Muhammad yang diperkirakan baru memeluk Islam sesudah penaklukan Khaibar pada tahun $629 \mathrm{M}$ sesaat sebelum peristiwa pembebasan Mekkah (Umairah, 2000:178) Dengan demikian, sangatlah tidak mungkin Abbas R.A. mendengar pengisahan isra mikraj langsung dari Nabi $(621 \mathrm{M})$. Namun, dapat dimungkinkan apabila yang dimaksud penulis $H N M$ adalah Abdullah bin Abbas, anak dari Abbas R.A.

2. HNM diawali dengan pengutusan Malaikat Jibril dan Mikail untuk bertemu Nabi Muhammad S.A.W. dan langsung diajak untuk isra mikraj seperti dalam penggalan naskah berikut

Maka kata Jibril dan Mikail, "Ya Muhammad! Berjanjilah tuan hamba dengan buraq itu. Turunkanlah sayap katanya itu maka hamba pun berkata pada buraq itu demikian kata hamba, "Hai buraq! Bahwalah tiadalah aku mengendarai buraq yang lain daripadamu pada hari kiyamat. "(Sa'idullah, 1825)

Adapun di dalam Sahih Bukhari nomor 3887 diawali dengan penceritaan Nabi S.A.W. kepada sahabatnya tentang peristiwa pembelahan dan pembersihan hati Nabi oleh Malaikat Jibril, seperti sabda Nabi berikut.

\footnotetext{
${ }^{1}$ Perawi: Orang yang meriwayatkan hadis Nabi Muhammad SAW (KBBI V Luring)
} 


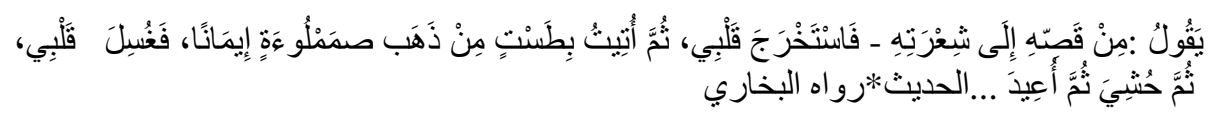

(Yaqūlu: min qașsihi ilā syi'ratihi-fastakhraja qalb, summa utītu bițastin min zahabi șamamlau'atin ìmānan, fagusila qalbī, śsmma husyì siumma u'ida)

"Lalu laki-laki itu mengeluarkan kalbuku (hati), kemudian dibawakan kepadaku sebuah baskom terbuat dari emas yang dipenuhi dengan iman, lalu dia mencuci hatiku kemudian diisinya dengan iman dan diulanginya. Kemudian aku didatangkan seekor hewan tunggangan berwarna putih yang lebih kecil dari pada baghal namun lebih besar dibanding keledai" (Al-Bukhari, 2017)

3. Terdapat kesamaan mengenai penggunaan hewan Burak ${ }^{2}$ dalam peristiwa isra mikraj. Dalam Bukhari, diceritakan bahwa Nabi Muhammad S.A.W. dibawakan hewan Burak sebagai kendaraan dalam menjalankan isra mikraj, seperti sabda Nabi berikut:

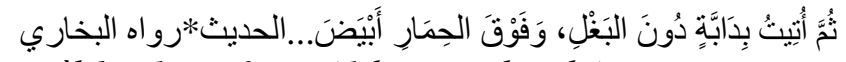

(Śumma utītu bidābbatin dūna 'l-bagli, wafauqa 'l-ḥimāri abyaḍa)

"Kemudian aku didatangkan seekor hewan tunggangan berwarna putih yang lebih kecil dari pada baghal namun lebih besar dibanding keledai" (Muhammad bin Ismail Al-Bukhari, 2017)

Adapun tetulis pula dalam $H N M$ saat Jibril dan Mikail membawakan Burak pilihan dari surga kepada Nabi Muhammad S.A.W. Berikut ini kutipannya.

Maka kata Jibril dan Mikail," Ya Rasulullah! Inilah yang bernama Buraq akan kenaikan tuan hamba. "(Sa'idullah, 1825:12)

4. Disajikan perbedaan antara kedua teks. Dalam $H N M$ dijelaskan bahwa Nabi Muhammad S.A.W. ditemui oleh dua Malaikat, yaitu Jibril dan Mikail. Hal ini sebagaimana tertulis dalam HNM bahwa Nabi Muhammad bertanya kepada Jibril dan Mikail tentang hewan yang akan dinaikinya dan kemudian dijawab oleh Mikail dan Jibril bahwa hewan yang akan dinaiki Nabi Muhammad bernama burak (Sa'idullah, 1825:12). Sedangkan dalam hadis, dijelaskan hanya Malaikat Jibril saja yang membersamai Nabi Muhammad. Hal ini dapat dilihat dari penggalan hadis berikut.

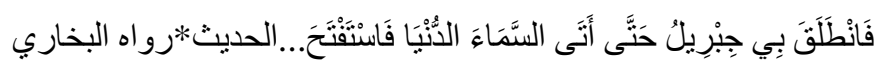

(Fanțalaqa bī jibrīlu ḥatta ata `l-samā’'a 'l-dunyā fastaftaḥa)

Lalu aku menungganginya kemudian aku berangkat bersama Jibril 'alaihis salam hingga sampai di langit dunia (Muhammad bin Ismail Al-Bukhari, 2017)

\footnotetext{
${ }^{2}$ Burak atau Buraq; kendaraan berupa hewan yang digunakan Nabi Muhammad ketika isra Mikraj
} 
Dalam $H N M$ disebutkan peristiwa-peristiwa tentang siksaan di neraka, sedangkan dalam hadis Bukhari 3887 tidak diceritakan. Hal ini dapat dilihat dari penggalan HNM berikut:

Bibirnya seperti bibir unta, maka mulutnya dituang oleh malaikat dengan tembaga.(Sa'idullah, 1825)

5. Dalam Naskah HNM disebutkan beberapa nama yang asing, seperti malaikat Thail (Sa'idullah, 1825:113), malaikat Kanzu l-`Nar (Sa'idullah, 1825:117), malaikat tujuh puluh muka (Halaman 68) yang tentu tidak terdapat dalam hadis Bukhari nomor 3887.

6. Kedua teks sama-sama menceritakan bahwa di setiap tingkatan langit terdapat Nabi yang mendiaminya. Hal ini dapat dilihat pada teks yang mempertemukan Nabi Muhammad SAW pada Nabi yang lain di setiap lapisan langit. Berikut dapat dilihat nama-nama Nabi dan lapisan langitnya. (Sa'idullah, 1825)

\section{Tabel 1}

Perbandingan Nabi di Setiap Lapis

\begin{tabular}{|c|c|c|c|}
\hline No & Lapisan Langit & HNM & Bukhari \\
\hline 1 & Pertama & Ismail AS & Adam AS \\
\hline 2 & Kedua & - & Yahya AS dan Isa AS \\
\hline 3 & Ketiga & $\begin{array}{l}\text { Yusuf AS, Daud AS, dan } \\
\text { Sulaiman AS }\end{array}$ & Yusuf AS \\
\hline 4 & Keempat & $\begin{array}{l}\text { Ibrahim AS, Ismail AS, Ishak } \\
\text { AS, dan Luth AS. }\end{array}$ & Idris AS \\
\hline 5 & Kelima & - & Harun AS \\
\hline 6 & Keenam & Nuh AS dan Idris AS & Musa AS \\
\hline 7 & Ketujuh & Musa AS & Ibrahim AS \\
\hline
\end{tabular}

Terdapat sisi menarik dari $H N M$ dalam hal penceritaan kondisi setiap lapis langit. Penceritaan penghuni langit yang seharusnya dihadirkan dengan memunculkan nama-nama Nabi di setiap lapis, justru lebih ditonjolkan nama-nama malaikat disertai ciri dan tugasnya. Sebaliknya, penampilan nama-nama Nabi yang berkedudukan sebagai ikon dari hadis justru tidak ditonjolkan bahkan tidak lengkap.

7. Kedua teks sama-sama menceritakan kisah ujian Nabi Muhammad saat isra mikraj tentang urusan minuman. 
"Maka hamba ambil piala yang berisi susu itu. Hamba minum tiada habis tinggal lagi sedikit. Maka kata Jibril,"Ya Muhammad terlalu berbahagia tuan hamba. Maka piala yang berisi susu itu tuan hamba minum." (Sa'idullah, 1825)

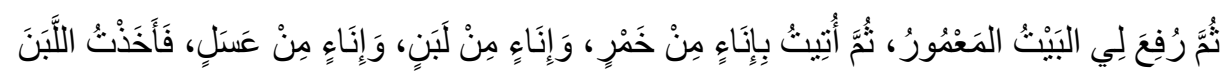

Tumma rufi'a lì 'l-baitu 'l-ma'mūru, țumma utītu bi inā'in min khamrin, wa inā'in min laban, wa inā' in min 'asalin, fakhażtu 'l-labana)

"Kemudian aku diangkat ke Baitul Ma'mur, lalu aku diberi satu gelas berisi khamer, satu gelas berisi susu dan satu gelas lagi berisi madu. Aku mengambil gelas yang berisi susu. Maka Jibril berkata; "Ini merupakan fithrah yang kamu dan ummatmu berada di atasnya". (Muhammad bin Ismail Al-Bukhari, 2017)

8. Dalam hadis Bukhari nomor 3887 ditampilkan cerita tentang asal mula perintah salat lima waktu sebagai tujuan inti dari peristiwa isra mikraj. Namun, dalam $H N M$ justru hanya sedikit pembahasan mengenai hal tersebut.

Maka firman Allah Taala,"Hai Muhammad kerjakan olehmu dengan segala ummatmu sembahyang pada sehari semalam lima waktu dan puasa dalam setahun sebulan pada bulan Ramadan." (Sa'idullah, 1825)

Dari perbandingan di atas dapat dilihat bahwa $H N M$ memiliki beberapa persamaan dan juga kemiripan dengan hadis Bukhari nomor 3887. Meskipun terdapat beberapa perbedaan diantara keduanya. dalam teks $H N M$ dijumpai penyebutan nama dan peristiwa yang tidak dijumpai dalam hadis Bukhari nomor 3887. Begitu pula sebaliknya, terdapat nama dan peristiwa dalam hadis Bukhari nomor 3887 yang tidak dijumpai dalam teks $H N M$. Namun demikian, data-data perbandingan kedua teks tersebut cukup membuktikan bahwa teks HNM merupakan teks hasil transformasi dari hadis Bukhari nomor 3887. Artinya, teks HNM lahir dari interpretasi penulis terhadap kisah isra' mikraj yang temuat dalam hadis Bukhari nomor 3887. Hubungan ini dilihat sebagai fenomena intertekstual.

Kemudian yang perlu diperhatikan dalam kajian intertekstual HNM dan hadis Bukhari nomor 3887 adalah bahwa HNM merupakan naskah Melayu yang menampilkan kisah-kisah yang bersifat fiksi yang diangkat berdasarkan sebuah peristiwa yang diyakini sebagai fakta (peristiwa isra mikraj). Penggambaran mengenai malaikat, peristiwa yang terjadi di alam neraka, peristiwa yang terjadi di surga, dan kisah-kisah lain seperti kisah pasca penceritaan kisah isra mikraj yaitu tentang orang Bani Israil yang tidak percaya atas peristiwa isra mikraj ditulis dengan sifat yang imajinatif. Akibatnya, timbul perbedaan-perbedaan dengan realita yang ada dalam penceritaan hadis-hadis mutawatir.

\section{PENUTUP}

Dengan menggunakan perbandingan data-data tekstual terhadap HNM dan hadis Bukhari dengan menggunakan pendekatan intertekstual, dapat disimpulkan 
Tuah Talino

Tahun XIV Volume 14 Nomor 1 Edisi 31 Juli 2020

ISSN 0216-079X E-ISSN 2685-3043

Balai Bahasa Kalimantan Barat

bahwa teks $H N M$ adalah teks transformasi dari teks hadis Bukhari yang memiliki kedudukan sebagai teks hipogram $H N M$.

Hal yang harus diperhatikan adalah peristiwa isra mikraj adalah peristiwa yang suci bagi umat Islam dan sangat diyakini kebenarannya. Adapun HNM adalah prosa Melayu yang bersifat fiktif. Oleh karena itu, bagi pembaca awam yang kurang dalam pengetahuan agama Islam atau tidak paham betul atas kisah asli dari isra mikraj, $H N M$ memiliki kecenderungan untuk menyesatkan. Karena terdapat butir-butir penceritaan yang tidak sesuai dengan cerita aslinya.

Namun, harus diakui pula bahwa $H N M$ sebagai karya imajinatif yang poliinterprestasi, tentu memiliki unsur-unsur tersirat yang dapat ditangkap oleh pembaca. Misalnya, dengan kemasan cerita yang dibuat menarik seperti dalam teks $H N M$, pembaca akan lebih bisa memaknai keagungan peristiwa isra mikraj sehingga iman dan takwanya pada Allah SWT atas kebesaran-Nya semakin bertambah.

\section{DAFTAR PUSTAKA}

Baried, S. B. (1994). Pengantar Teori Filologi. Yogyakarta: Badan Penelitian dan Publikasi Fakultas, Seksi Filologi UGM.

KBBI V Luring. (2016). Jakarta: Badan Pengembangan Bahasa dan Perbukuan Kementrian Pendidikan dan Kebudayaan Republik Indonesia.

Mamat, W. A. H. W. (1988). Pemuliharan Buku dan Manuskrip. Kuala Lumpur: Dewan Bahasa dan Pustaka Kementerian Pendidikan Malaysia.

Mardalis. (2004). Metode Penelitian: Sebuah Pendekatan Proposal. Jakarta: Bumi Aksara.

Maria, U. (2015). Studi Kisah Isra' Mi'raj dalam Al Qur'an (Thesis).Surabaya:UIN Sunan Ampel

Muhammad bin Ismail Al-Bukhari. (2017). Sahih Bukhari. Beirut: Dar 1-`kutub 1"Ilmiyah.

Mulyadi, S. W. R. (1991). Kodikologi Melayu di Indonesia. Depok: Fakultas Sastra Universitas Indonesia.

Muzakka, M. (2018). Hubungan Intertekstualitas Syair Paras Nabi Dan Hikayat Nabi Bercukur. Nusa: Jurnal Ilmu Bahasa dan Sastra, 13(3), 341. https://doi.org/10.14710/nusa.13.3.341-350

Sa'idullah, M. C. (1825). Hikayat Nabi Mikraj. Perpustakaan Nasional Prancis. Suryadi, S. (2015). Isra Mikraj dalam Naskah-Naskah Indonesia. Studia Islamika, 22(2). https://doi.org/10.15408/sdi.v22i2.1923

Teeuw, A. (1982). Khazanah Sastra Indonesia. Jakarta: Balai Pustaka.

Tohopi, R. (2012). Tradisi Peraraan isra' Mi'raj dalam budaya islam Lokal Masyarakat gorontalo. El-HARAKAH (TERAKREDITASI), 14(1), 135-155. https://doi.org/10.18860/el.v0i0.2192

Umairah, A. (2000). Tokoh-Tokoh yang Diabadikan dalam Al Quran. Jakarta: Gema Insani Press. 